Ks. Janusz Węgrzecki

\title{
Rozum polityczny a supozycje z teologii krzyża Josepha Ratzingera
}

\author{
Political Reason and Suppositions \\ from the Theology of the Cross of Joseph Ratzinger
}

\begin{abstract}
Abstrakt: Autor podejmuje próbę wyprowadzenia supozycji zawartych w teologii krzyża J. Ratzingera dla rozumu politycznego. Podkreśla, że teologia krzyża stanowi klucz interpretacyjny dla wszelkiego typu działania człowieka, w tym także jego działania w obszarze polityki.
\end{abstract}

Słowa kluczowe: Ratzinger, Benedykt XVI, rozum, polityka, teologia krzyża

Abstract: The Author makes an attempt to draw suppositions from the theology of the cross of J. Ratzinger regarding political reason. He emphasizes that the theology of the cross constitutes a key to interpret all types of human activity, including the activity in the field of politics.

Key words: Ratzinger, Benedict XVI, reason, politics, theology of the cross

Wybitny teolog i myśliciel Joseph Ratzinger, późniejszy papież Benedykt XVI, szukając zrozumienia działania Boga i człowieka skierował swoją uwagę na teologię krzyża. W jego przekonaniu teologia krzyża staje się kluczem interpretacyjnym wszelkiego działania człowieka. Jeśli wszelkiego działania, to także działania w odniesieniu do polityki. Pytanie badawcze stawiane w artykule jest następujące: Czy z teologii krzyża dają się wyprowadzić implikacje dla działania polityka, dla rozumu politycznego? Takiego pytania nie postawił sam Joseph Ratzinger. W artykule postawiona jest hipoteza, że możliwe jest ukazanie supozycji zawartych w teologii krzyża, tak jak ją przedstawia Ratzinger, dla rozumu politycznego. Kolejna hipoteza, że zinterpretowane supozycje należą do etyki politycznej. Konsekwentnie podejście badawcze przyjęte $\mathrm{w}$ artykule ma charakter interpretacjonistyczny. Artykuł stanowi próbę nowatorskiej autorskiej interpretacji 
wyprowadzenia z teologii krzyża Ratzingera wskazań etyczno-politycznych dla rozumu politycznego.

Joseph Ratzinger bardzo realistycznie patrzy na człowieka i jego życie. Zarówno w wymiarze prywatnym, jak i publicznym. Dostrzega to, co jest pozytywne. Stworzony świat, który jest piękny, dobry, wspaniały, którego struktura - natura jest nośnikiem odkrywanej prawdy. Dostrzega również to, co jest negatywne. Słabość ludzka, uleganie złu, które w wymiarze społecznym prowadzi do niesprawiedliwości i naruszenia pokojowego współżycia. Wymiar pozytywny, w interpretacji teologicznej wiąże z Wcieleniem, gdy Logos staje się człowiekiem. Ukazuje się oblicze Boga, który jest jednocześnie Logosem i Miłością. Z tego obrazu wynika podwójna pozytywność, z którą człowiek ma do czynienia. Logos przynosi sens oraz wartości, jak prawda, dobro, piękno. Miłość przynosi nową tożsamość człowiekowi i nowy kształt relacjom międzyludzkim, w tym społecznym i publicznym. Człowiek doświadcza i uświadamia sobie, że jest przez Logos, który zarazem jest Miłością, jest wybrany, chciany i umiłowany. To doświadczenie prowadzi do kształtowania odpowiadających mu relacji społecznych. Człowiek człowiekowi bratem, a nie jak chciał Hobbes wilkiem.

Teolog Bawarski wymiar negatywny wiąże z teologią krzyża. Istnieje w człowieku pęknięcie, skłonność do zła. Ratzinger zdecydowanie ukazuje przewagę strony pozytywnej nad negatywną, podkreślając potencjał zniszczenia, który może się ujawnić. Dla rozumu politycznego z teologii krzyża płynie kilka implikacji. Teologia krzyża po pierwsze, upewnia o prymacie tego, co pozytywne, nad tym, co negatywne. Po drugie, każe nie lekceważyć destrukcyjnych sił tkwiących w człowieku z możliwością kształtowania relacji publicznych i społecznych. Po trzecie, odrzuca determinizm zdominowania życia indywidualnego i zbiorowego przez negatywne siły. Teologia krzyża jest obrońcą wolności człowieka. To człowiek w swojej wolności kształtuje dzieje. Może je kształtować pozytywnie. Po czwarte, nawet po zwycięstwie mocy negatywnych, zawsze można wrócić do tego, co pozytywne. Po piąte, panowanie sił negatywnych jest ściśle ograniczone. Prymat tego, co pozytywne powoduje, że człowiek będzie poszukiwał sensu i zwracał się ku temu, co prawdziwe i dobre, tym samym, podejmując wysiłki zrzucenia panowania sił negatywnych nad sobą oraz relacjami publicznymi i społecznymi. Po szóste, teologia krzyża podpowiada skuteczne sposoby przezwyciężenia tego, co negatywne, a co umożliwia, aby to, co pozytywne kształtowało życie ludzkie, zarówno w wymiarze prywatnym, jak i publicznym. 
Teologia krzyża zawiera bardzo bogaty rezerwuar sensów do wykorzystania w polityce. Polityk wiele może się nauczyć zapoznając się z teologią krzyża. Rozum polityczny, wiele na to wskazuje, bardzo zyskuje z rozważania treści, które odsłania teologia krzyża.

Zacznijmy od stosunku Boga do ludzi. Ten stosunek staje się modelem traktowania ludzi przez polityka. Ratzinger twierdzi: „Ty jesteś przepełniony szczodrą miłością; Ty nie kochasz tak, jak kochają ludzie, którzy mogą być dobrzy dla drugiego tylko wtedy, gdy wydaje się im on sympatyczny, gdy do nich pasuje, gdy ma coś do zaoferowania, a nie zawsze tylko do brania, do żebrania" [Ratzinger 2017: 711]. Fundamentalne pytania, które powinien w związku z powyższym zadać rozum polityka. Czym jest polityka? Jaki jest sens bycia politykiem? Kim są ci, których dotyczy działalność polityka? Jak należy ich traktować, jaki powinien być stosunek względem nich? Rozum polityczny, który politykę traktuje jako realizację odkrywanego sensu (rozum polityka chrześcijańskiego utożsamia sens ostatecznie z Bogiem, rozum polityka agnostyka z wartościami) oraz poszukiwanie wartości i działanie zgodnie z nimi, powyższy model potraktuje jako normę własnego postępowania. Głębszą motywację polityk znajdzie w spojrzeniu jakie jest jego miejsce w relacji do Logosu. „Ostatecznie wszyscy - zgodnie z genialnymi słowami św. Augustyna - nie jesteśmy nikim innym jak żebrakami Boga. Żebrak, który jest pyszałkowaty i dumny, który zachowuje się jak bogacz, jest godnym pożałowania głupcem. Człowiek, który postępuje tak, jakoby nie potrzebował Bożych darów, lecz sam mógłby dawać sobie radę, jest głupcem w nie mniejszym stopniu" [Ratzinger 2017: 711]. Polityk jako polityk, tak jak każdy człowiek w swojej wielorakiej działalności nie jest samowystarczalny. Z rozważania modelu traktowania ludzi przez Boga nabiera świadomości kim jest, po co jest i jaki powinien być dla stanowiących przedmiot własnej aktywności politycznej. Znajduje także upewnienie, że nie może polegać wyłącznie na własnych siłach i że może liczyć na niezawodne wsparcie, gdy w swojej aktywności politycznej traktuje innych z życzliwością i kierując się ich dobrem, czyli dobrem wspólnym.

Kolejne samozrozumienie czerpie polityk z modelu wybrania Syna Bożego. Ukrzyżowany nie jest nikim innym jak wybranym. „W Ukrzyżowaniu mogą wierzący ujrzeć znaczenie owej wyroczni, znaczenie wybrania; nie przywileje i potęga dla siebie, tylko służba dla innych" [Ratzinger 2017: 179]. Z tego modelu rozum polityczny czerpie zrozumienie, że polityka jest służbą. Takie zrozumienie jest oczywiste dla polityka chrześcijanina. Krąg rozumiejących jest jednaki znacznie szerszy. Wystarczy wspomnieć Mahatmę Gandhiego, którego działalność 
miała charakter służebny wobec współczesnej mu społeczności indyjskiej, który jednak chrześcijaninem nie był.

Droga krzyżowa odsłania kolejny sens rozumowi politycznemu. Teolog Bawarski twierdzi: „droga krzyżowa jest drogą utraty siebie, czyli drogą prawdziwej miłości” [Ratzinger 2017: 776]. Jakie z tego wynikają implikacje dla polityka? Najgłębszym sensem aktywności politycznej jest życzliwość, dobro, współczucie, czyli miłość tych, których dotyczą decyzje polityczne. Czy miłość jako czynnik sprawczy życia publicznego jest zrozumiały wyłącznie przez chrześcijan? Na tyle, na ile miłość jest fenomenem ludzkim, może stać się czynnikiem politycznym uwzględnionym przez każdy rozum polityczny.

Ostatnia sprawa może rodzić pytanie, czy nie za dużo oczekuje się od polityka? Z poziomu teologicznego przychodzi jednoznaczna odpowiedź. Ratzinger stwierdza: „Bóg ofiaruje samego siebie. Jeżeli Boża miara jest nadmiarem, to także dla nas nic wobec Boga nie powinno być za dużo (...). W fetorze rozkładu ideologii nasza wiara powinna znów stać wonią, która naprowadza nas na ślad życia" [Ratzinger 2017: 794]. Od polityka jako polityka także można oczekiwać nadmiaru. Rozum polityka, który otwiera się na nadmiar, możliwy jest tylko w ramach racjonalności, która przekracza racjonalność oświecenia, pozytywizmu (cywilizacji naukowo-technicznej) oraz ideologii. Taka szersza, otwarta racjonalność dostępna jest wszelkiemu rozumowi.

Polityk, aby był jednak zdolny do tej postawy „nadmiaru”, powinien przejść drogę intelektualnego i duchowego dojrzewania, która jest także trudnym procesem oczyszczania. „Owoc i miłość stanowią jedno. Prawdziwym owocem jest miłość, która przeszła przez Krzyż, przez Boże oczyszczenie” [Ratzinger 2015a: 313]. Modelem tego oczyszczenia jest obraz Boga. „Kardynał Newman stwierdził kiedyś, że Bóg mógł bez trudu stworzyć kosmos, w całej jego wielkości, jednak aby przyprowadzić człowieka i ludzi do siebie, kosztowało Go to nieskończony trud stania się człowiekiem i własną śmierć. Tylko przez zaangażowanie własnego istnienia można stać się pasterzem ludzi” [Ratzinger 2012b: 314]. Polityk, które pragnie być pasterzem ludu, bardziej przypomina Boga zbawcę, który liczy się z wolą ludzi, niż wszechpotężnego Boga stworzyciela.

Istnieje zbieżność doświadczenia polityka oraz tego ukazywanego w teologii krzyża. Bywają momenty, gdy polityk pozostaje sam. Z wiedzą ekspercką, informacjami niejawnymi, w otoczeniu doradców. Pomimo tego pozostawiony sam 
sobie, aby prawidłowo zdecydować. „Jakże często wydaje się, że śpisz. Jak łatwo my, ludzie, możemy odwrócić się i powiedzieć: Bóg umarł. Pozwól nam w godzinach ciemności rozpoznać, że to jednak jesteś Ty. Nie zostawiaj nas samych, kiedy tracimy nadzieję" [Ratzinger 2017: 793]. Istnieją chwile w życiu polityka, kiedy powinien otworzyć się na sens, który w cierpliwości i samotności zostaje odkryty. W tym chwytaniu sensu, nikt, z bliższego i dalszego otoczenia, ani nic, czyli inna racjonalność (oświeceniowa, ekspercka, ideologiczna) nie mogą pomóc. Zdobywa się ją samemu od Logosu i od obiektywnych wartości.

Polityk może wiele nauczyć się od kultu Serca Jezusowego, ściśle wywodzącego się z teologii krzyża. Był on ruchem Jezusa wewnątrz Kościoła. „Nad rumowiskiem wojny trzydziestoletniej, pośród politycznego chrześcijaństwa dworów barokowych odkrył on prostotę Jezusa i związał Kościół na nowo z Jego prostotą" [Ratzinger 2017: 803]. Metaforom rumowiska i dworów barokowych odpowiadać mogą formułowane utopie polityczne czy splendor polityczny. Zasłaniają one to co jest istotą polityki: dobro społeczeństwa, czyli dobro wspólne. Polityk potrzebuje niekiedy powrotu do tej prostoty spojrzenia, aby nie zagubić prawdziwego sensu polityki.

Jednym z oczekiwań działalności politycznej jest natychmiastowa i widzialna skuteczność. Nasuwa się podobieństwo do Kościoła, który swoją działalność i „sukcesy” powinien oceniać z perspektywy teologii krzyża. „Kościół przez całą swoją historię pozostanie ziarnkiem gorczycy. On żyje zawsze z niepojętej mocy Ducha Świętego, a nie ze zdobytej władzy swojej organizacji” [Ratzinger 2017: 804]. Istnieje wymiar działalności politycznej, który nie daje się przełożyć na rozwiązania instytucjonalne, wymierne osiągnięcia społeczne czy gospodarcze. Wymiar, który dla polityka wiąże się z pojęciem męża stanu, postawą i decyzjami, których wielkość docenia się po latach. De Gaspari, Adenauer, Schuman, ich działalność pozostawiła takie „ziarnko gorczycy”, które rośnie i dojrzewa w ciągu dalszej historii. Do której nawiązują kolejne pokolenia polityków.

Teologia krzyża daje pełniejsze zrozumienie Błogosławieństw z Kazania na Górze Chrystusa. Ubóstwo w duchu, oznacza, że „odnowa Kościoła może wyjść tylko od tych, w których jest żywa ta sama stanowcza pokora i gotowa do służenia dobroć” [Ratzinger 2015a: 181]. Podobnie odnowę polityki może dokonać tylko polityk, będący ubogim w duchu, pokornym i dobrym, traktującym swoją działalność jako służenie, czyli realizowanie dobra wspólnego. Błogosławieni cisi, czyli łagodni, pokorni, którzy nie stosują przemocy, którzy tworzą obszar pokoju. „Celem pokoju 
jest zniesienie granic i ziemia odnowiona poprzez pochodzący od Boga pokój. Ziemia - jak mówi nam Pan - ostatecznie należy do łagodnych, wprowadzających pokój. Powinna się stać ziemiq Króla pokoju” [Ratzinger 2015a: 186]. Ważne są zatem i cele i metody, środki, także retoryczne. Czy możliwa jest polityka, której celem jest łączenie, jednanie zwaśnionych, prowadzona bez przemocy, przynajmniej mentalnej, psychicznej, retorycznej? Polityka prowadzona pozytywnie, a nie przeciw komuś? Powyższe błogosławieństwa upewniają, że tak.

Błogosławieni, którzy się smucą, albowiem oni będą pocieszeni. „Są dwa rodzaje smutku: smutek, który utracił nadzieję, który nie ufa już miłości i prawdzie i dlatego demoralizuje człowieka i niszczy go od środka; ale istnieje też smutek, który pojawia się jako wstrząs wywołany w człowieku przez prawdę, smutek prowadzący człowieka do nawrócenia i do stawiania oporu złu” [Ratzinger 2015a: 187]. Polityk, który kieruje się prawdą, nie traci nadziei na przezwyciężenie zła, które napotyka na swej politycznej drodze. Jest „smutny” z powodu zła, ale nie godzi się na to zło i przezwycięża je, ale stosując jedynie dobre środki.

Pragnienie sprawiedliwości i prześladowanie dla sprawiedliwości. W Starym Przymierzu sprawiedliwość polega na „trzymaniu się ukazanej przez Boga drogi prawdy, której centrum stanowi Dekalog”. W Nowym Przymierzu na wierze, „albowiem wiara oznacza dać się porwać Chrystusowi, w którym wypełniło się całe Prawo; ona łączy nas ze sprawiedliwością samego Chrystusa" [Ratzinger 2015a: 189]. Sprawiedliwość w polityce w świetle tych błogosławieństw oznacza poznanie prawdy o wartościach, przyjęcie, interioryzacja obiektywnych wartości, realizowanie wartości w działalności i w decyzjach politycznych. Bez względu na cenę i spotykany opór polityk wybierze wartości. Wie bowiem, że polityka jest sprowadzaniem wartości w świat międzyludzki, w ramach instytucji państwa, kultury, gospodarki, polityki społecznej.

Błogosławieństwa są ukrytą chrystologią. „Za nią kryje się postać Chrystusa, Człowieka, który jest Bogiem, ale właśnie dlatego uniża się i ogołaca, aż po śmierć na Krzyżu. (...) Jednym słowem: prawdziwą moralnościq chrześcijaństwa jest miłość. Ta zaś przeciwstawia się oczywiście egoizmowi - jest wyjściem z siebie, ale właśnie w ten sposób człowiek siebie odnajduje”. Czy możliwe jest, aby polityk traktował ten obraz poważnie? I jak wypada w porównaniu chociażby z obrazem nakreślonym przez Nietzschego? „W porównaniu z kuszącym blaskiem obrazu człowieka u Nietzschego droga ta wydaje się zrazu uboga, a nawet zniechęcająca”. Który obraz człowieka powinien stać się podstawą polityki? Ten z Błogosławieństw 
to „prawdziwa droga na wyżynach życia” [Ratzinger 2015a: 196]. Która z tych polityk jest polityką z ludzką twarzą? Odpowiedź wcale nie wydaje się retoryczna.

Teologia krzyża odkrywa przed politykiem wymiar, który na ogół z trudnością kojarzy się z polityką. Ratzinger stwierdza „że na krzyżu Jezusa Chrystusa wszystkie ofiary spełniły się; w Nim dokonało się to, co było intencją wszystkich ofiar - ekspiacja - i w ten sposób sam Jezus zajął miejsce świątyni, On sam jest nową świątynią" [Ratzinger 2015: 410-411]. Istnieją sytuacje w polityce, które wymagają ekspiacji. Powrót do normalności, po wojnie, zamieszkach i podobnych sytuacjach wymaga czegoś więcej niż tylko działań na powierzchni polityki. Wchodzimy tutaj w obszar duchowości polityki. Czy polityk musi na ten wymiar pozostać ślepym i głuchym, i czy odważny polityk nie powinien się do niego odwołać?

„Nie istnieje sprzeczność między radosnym orędziem Jezusa a przyjęciem przez Niego Krzyża jako śmierci za wielu. Przeciwnie: dopiero w Jego przyjęciu śmierci i przemianie śmierci to radosne przesłanie łaski osiąga całą swoją głębię" [Ratzinger 2015: 469]. Własne doświadczenie nauczy polityka, że nawet najlepszy program, dobre intencje wymagają osobistej ofiary, ekspiacji. To, co wartościowe kosztuje. Za realizacje wartości płaci się określoną życiową cenę. Rachunek bowiem wystawia zło, którego przezwyciężenie kosztuje określoną cenę. „Realność zła, niesprawiedliwości, która deformuje świat i jednocześnie brudzi obraz Boga - ta rzeczywistość jest obecna tu poprzez naszą winę. Nie można jej po prostu zignorować, lecz należy ją przezwyciężyć” [Ratzinger 2015a: 542]. Polityk realizujący wartości zmaga się jednak z ludzką winą, która przynosi realność zła i niesprawiedliwości. Przezwyciężyć tej winy sam nie może. Powinien się zatem otworzyć na duchowe siły, które są w stanie winy przezwyciężyć. Polityka, aby mogła być dalej dobrze prowadzona wymaga przezwyciężenia winy. W tym przypadku rozum polityczny wymaga szerszej racjonalności. „Tajemnica przebłagania nie może być powierzona wszechwiedzącemu racjonalizmowi” [Ratzinger 2015a: 547]. Na to, co pozwala przezwyciężyć winę wskazuje przebite serce Jezusa. „To serce nie jest zachowywaniem siebie samego, lecz darem z siebie. Ocala świat przez otwarcie się. (...) Serce wprawdzie ocala, ale ocala przez dar z siebie" [Ratzinger 2015b: 631].

Teologia krzyża stawia rozum polityczny wobec faktu permanentnego ludzkiego zła, które w nowych odsłonach daje i będzie dawało znać o sobie. Przykłady z niedawnej przeszłości. „To jest Wielki Piątek XX w.: oblicze człowieka jest wyszydzane, opluwane, niszczone przez samego człowieka. Z komór gazowych Oświęcimia, ze spustoszonych wiosek i od udręczonych dzieci w Wietnamie; 
z dzielnic nędzy w Indiach, Afryce i Ameryce Łacińskiej, z obozów koncentracyjnych komunistycznego świata, które z poruszającymi szczegółami ukazał naszym oczom Sołżenicyn - zewsząd spogląda na nas «skrwawiona i pokryta ranami, naznaczona cierpieniem głowa, będąca przedmiotem drwin i szyderstw»" [Ratzinger 2015b: 585]. Dzieje się tak dlatego, że w dziedzinie wolności, w obszarze moralności nie ma prostego postępu. Wielki błąd popełnia tutaj racjonalność oświecenia. Myli się Kant i Hegel i Marks. „Gdyby Kant i Hegel mieli rację, wtedy postępujące oświecenie musiałoby czynić człowieka coraz bardziej wolnym, rozumnym i sprawiedliwym. Zamiast tego, z jego wnętrza wynurzają się coraz straszniejsze demony, zbyt pospiesznie uznane za martwe, i uczą człowieka odczuwania trwogi przed swą własną siłą i bezsilnością; przed własną siłą niszczenia, przed niemocą odnalezienia siebie samego i zapanowania nad własnym brakiem ludzkich uczuć i odruchów [Ratzinger 2015b: 585-586]. Polityk z całym realizmem musi sobie uzmysławiać, że nie uniknie radzenia sobie z własną i innych (społeczeństwa politycznego) siłą i bezsilnością oraz implikacji, które z nich wynikają.

Teologia krzyża ukazuje najskuteczniejszy sposób trwałej pozytywnej przemiany świata. Jeśli rozum polityczny pragnie takiej przemiany dla „swojego” świata politycznego, czy nie powinien pozostawać w zasięgu takiego sposobu oddziaływania? „Ustanowienie na tym świecie znaku doskonałej miłości jako ukrytej siły jego przemiany stanowi czyn Boga; to, że ten znak otrzymuje postać krzyża - to dzieło człowieka” [Ratzinger 2015b: 952]. Istnieje prawo, że to co wartościowe przychodzi w niskości i ukryciu: „wszystkie prawdziwie owocne rzeczy na tym świecie mają swój początek w niskości i ukryciu. Bóg sam dostosował się ze swoim dziełem w świecie do tego prawa. Bóg sam pojawia się w tym czasie świata incognito, w postaci ubóstwa, bezsilności. A rzeczywistości Boga - prawda, sprawiedliwość, miłość - są małymi, deptanymi rzeczywistościami w tym świecie. A jednak to dzięki nim żyją ludzie, żyje świat, który nie mógłby istnieć, gdyby ich nie było. To właśnie one przetrwają, podczas gdy to, co głośne i władcze, już dawno się rozpadnie i zostanie zapomniane" [Ratzinger 2012b: 441]. To prawo zderza się z pewnego typu racjonalnością, która oczekuje czegoś całkowicie odwrotnego. „Bóg przychodzi jako baranek, a nie jako lew, wilk czy byk. W takiej postaci oczekiwali Go ludzie, jako pierwotnej siły, która ruszy struktury tego świata z posad i w ich miejsce stworzy zupełnie inne, która przyniesie dzień zemsty Boga. (...) On jednak nie przychodzi jako lew, pod którego postacią przedstawiają siebie stale królowie ziemscy” [Ratzinger 2012: 604]. Przed rozumem politycznym otwiera się sens, który ukazuje religia. „To wydaje się sprzeczne: chwała Boga i Ukrzyżowany. Jednak oba wymiary należą do siebie, a chwałę Boga poznaliśmy dopiero wtedy, 
gdy poznaliśmy Chrystusa jako Ukrzyżowanego. Prawdziwy Bóg nie panuje jak władca świata, wkraczając do akcji i niszcząc, nie włada, używając bomb, przemocy i siły techniki. On panuje w zupełnie inny sposób. Panuje, wchodząc między nas, kochając nas, cierpiąc z nami i za nas. Ta słabość jest prawdziwą siłą Boga, siłą, która wciąż odnawia świat, jedyną siłą, która przetrwa wszystkie upadki władzy w świecie i stale na nowo otwiera drzwi życia" [Ratzinger 2012b: 706].

Teologia krzyża przechodzi do wydarzenia zmartwychwstania. „I tylko wtedy, gdy rozumiemy je jako wydarzenie uniwersalne, jako zapoczątkowanie nowego wymiaru ludzkiej egzystencji, znajdujemy się na drodze prawidłowego rozumienia nowotestamentowego świadectwa o Zmartwychwstałym" [Ratzinger 2015a: 550]. Polityk czerpie z tego obrazu przeświadczenie, że swoją działalnością zapoczątkowuje nowy wymiar egzystencji ludzkiej w społeczności. Wnoszenie wartości w świat polityki, zwłaszcza po okresie destrukcji jest zawsze odnawianiem życia ludzkiego. Polityk, jak każdy człowiek pragnie przezwyciężenia tego, co także w wymiarze życia zbiorowego, społecznego i politycznego można nazwać śmiercią. Rozum polityczny staje wobec takiego wymiaru i takich zdarzeń, które wymagaja czegoś innego niż polityki publiczne, gospodarcza i społeczna, które symbolizuje chleb. „W swym najgłębszym wnętrzu człowiek nie żyje chlebem (polityka publiczna, gospodarcza, społeczna [przyp. j.w.]); w najistotniejszej sferze swego człowieczeństwa żyje tym, że jest kochany i że sam może kochać. Odkąd w sferze śmierci jest obecna miłość, odtąd w śmierci jest życie” [Ratzinger 2015b: 1024]. Rozum polityczny uzmysławia sobie, że odnowa życia politycznego musi przyjść z innego wymiaru niż polityki publiczne. I że istnieją mocne podstawy do nadziei na odrodzenie życia publicznego. Aby tak się stało, rozum polityczny powinien sięgnąć do tej siły i takiego wymiaru, który to umożliwia.

Pascha, czyli przejście ze śmierci do życia stawia pytanie o kryterium sukcesu. Przed takim pytaniem stoi również rozum polityczny. Pomiędzy machiawelizmem a teologią krzyża. Modelem dla polityka może być, z jednej strony Cezar czy Aleksander Wielki, a z drugiej strony Jezus. „Czy zatem Jezus poniósł porażkę? Otóż z całą pewnością nie odniósł sukcesu w takim sensie jak Cezar czy Aleksander Wielki. Z ziemskiego punktu widzenia była to z początku porażka. Zmarł niemal całkowicie opuszczony, został skazany za swoje słowa. Odpowiedzią na Jego orędzie nie było wielkie „tak” Jego ludu, lecz Krzyż. Taki koniec uczy nas, że sukces nie jest żadnym $\mathrm{z}$ imion Boga i że dążenie do sukcesu zewnętrznego i wymiernego nie jest chrześcijańskie. Drogi Boga są inne. Jego sukces przechodzi przez Krzyż i zawsze pozostaje pod tym znakiem. Przez całe wieki uwierzytelniaja 
go prawdziwie ci, którzy przyjęli ten znak.” [Ratzinger 2012a: 297]. Z jednej strony rozum polityczny ograniczony wyłącznie ziemskim punktem widzenia. $Z$ drugiej strony rozum polityczny otwarty na sens znaku jakim jest krzyż.

Ratzinger ukazuje teologię krzyża jako rezerwuar sensów niezbędnych człowiekowi do właściwego życia i funkcjonowania społecznego. Ten zbiór sensów ważny jest zatem także dla polityka. Rozum polityczny powinien otwierać się na te sensy. Uzyskane wyniki pokazują, że suponowane sensy wyprowadzone z teologii krzyża przynależą do etyki politycznej. W efekcie tak prowadzona polityka będzie niewątpliwie miała charakter bardziej humanistyczny. Zinterpretowane sensy przybierają bowiem w znacznym stopniu postać prakseologii etyki politycznej. Prowadzi to wszystko do konkluzji, że polityka prowadzona zgodnie z etyką polityczną, a nawet $\mathrm{z}$ wymiarem prakseologicznym etyki politycznej, będzie bardziej zgodna $\mathrm{z}$ prawdą kim jest człowiek, a zatem $\mathrm{w}$ efekcie prowadzona $\mathrm{w}$ ramach agnostycyzmu pozytywnego, tak jakby Bóg istniał. Taką politykę rekomenduje Joseph Ratzinger.

\section{Bibliografia:}

Ratzinger J. (2017), Opera omnia, t. IV: Wprowadzenie do chrześcijaństwa. Wyznanie - chrzest - naśladowanie, przekł. Biel R., Górecka M., (red.) Góźdź K., Górecka M., Lublin.

Ratzinger J. (2015a), Opera Omnia, t. VI/1: Jezus z Nazaretu. Studia o chrystologii, przekł. Górecka M., Szymona W., (red.) Góźdź K., Górecka M., Lublin.

Ratzinger J. (2015b), Opera Omnia, t. VI/2: Jezus z Nazaretu. Studia o chrystologii, przekł. Szymona W., (red.) Góźdź K., Górecka M., Lublin.

Ratzinger J. (2012a), Opera Omnia, t. XI: Teologia liturgii. Sakramentalne podstawy życia chrześcijańskiego, przekł. W. Szymona, (red.) Góźdź K., Górecka M., Lublin.

Ratzinger J. (2012b), Opera Omnia, t. XII: Głosiciele Słowa i słudzy Waszej radości. Teologia i duchowość sakramentu święceń, przekł. Górecka M., Rodkiewicz M., współpraca Kobienia J., Petruk D., (red.) Góźdź K., Górecka M., Lublin. 